\title{
Surfactant-based therapy against COVID-19: A review
}

\begin{abstract}
The coronavirus disease 2019 (COVID-19) has led to serious health and economic damage to all over the world, and it still remains unstoppable. The SARS-CoV-2, by using its S-glycoprotein, binds with an angiotensin-converting enzyme 2 receptor, mostly present in alveolar epithelial type II cells. Eventually pulmonary surfactant depletion occurs. The pulmonary surfactant is necessary for maintaining the natural immunity as well as the surface tension reduction within the lung alveoli during the expiration. Its insufficiency results in the reduction of blood oxygenation, poor pulmonary regeneration, lung fibrosis, and finally the respiratory system collapses. Exogenous surfactants have previously shown great promise in the treatment of infant respiratory distress syndrome, and they may also aid in the healing of damaged alveolar cells and the prevention of respiratory failure. Surfactant based therapy has been advised for the prevention of COVID-19, and the trials have begun around the world. Furthermore, greater research on the timing, dose, and the distribution of surfactant to the COVID-19 patients is required before this technique can be implemented in clinical practice.
\end{abstract}

Keywords: COVID-19, SARS-CoV-2, alveolar type-II cells, pulmonary surfactant, surfactant therapy

\section{Tensid-basierte Therapie gegen COVID-19: Ein Überblick.}

Zusammenfassung: Die Coronavirus-Erkrankung 2019 (COVID-19) hat weltweit zu schweren gesundheitlichen und wirtschaftlichen Schäden geführt und ist nach wie vor nicht zu stoppen. Das SARS-CoV-2 bindet mit seinem S-Glykoprotein an den AngiotensinConverting-Enzym-2-Rezeptor, der vor allem in alveolären Epithelzellen vom Typ II vorhanden ist. Schließlich kommt es zu einem Abbau des pulmonalen Surfactant (Tensids). Das pulmonale Tensid ist für die Aufrechterhaltung der natürlichen Immunität sowie für die Verringerung der Oberflächenspannung in den Lungenalveolen während der Ausatmung notwendig. Seine Insuffizienz führt zu einer Verringerung der Sauerstoffversorgung des Blutes, einer schlechten Lungenregeneration, einer Lungenfibrose und schließlich zum Kollaps des Atmungssystems. Exogene Tenside haben sich in der Vergangenheit bei der Behandlung des Atemnotsyndroms bei Säuglingen als sehr vielversprechend erwiesen, und sie können auch bei der Heilung geschädigter Alveolarzellen und bei der Vorbeugung von Atemversagen helfen. Eine Tensid-basierte Therapie wurde zur Vorbeugung von COVID-19 empfohlen, und die Studien haben weltweit begonnen. Darüber hinaus sind weitere Forschungen zum Zeitpunkt, zur Dosis und zur Verteilung von Tensid an die COVID-19-Patienten erforderlich, bevor diese Technik in der klinischen Praxis eingesetzt werden kann.

Homogeneous Catalysis Laboratory, Department of Chemistry, The University of Burdwan, Burdwan, 713104, West Bengal, India

Department of Chemistry, Hooghly Mohsin College, Chinsurah, West Bengal, India

Department of Chemistry, Visva-Bharati University, West Bengal, India
Stichwörter: COVID-19, SARS-CoV-2, alveoläre Typ-II-Zellen, pulmonales Surfactant, Surfactant-Therapie

\section{Introduction}

The virus that causes respiratory sickness and that is responsible for the COVID-19 pandemic is the severe acute respiratory syndrome coronavirus 2 (SARS-CoV-2). The World Health Organization (WHO) designated this outbreak as a "Public Health Emergency of International concern" on 30 January 2020 and then as a pandemic on 11 March 2020. Worldwide, almost 32 million people have died from this outbreak so far by May 2021 [1]. Moreover, the second wave of COVID-19 in India is now showing no signs of abating. The WHO recently reported that one in three coronavirus cases worldwide is reported in India [2]. This catastrophic event requires the development of an immediate multidisciplinary approach to contain the spread of the disease and prevent complications.

In COVID-19 infection of the lung, the SARS-CoV-2 damages the alveolar cells, leading to a reduction in pulmonary surfactants [3]. The infection may start with or without mild flu symptoms such as cough and cold, or progress to more severe symptoms such as pneumonia, dyspnoea and hypoxia. However, in more severe cases, interstitial inflammation, a huge cytokine storm and pulmonary infiltrates occur, followed by acute respiratory distress syndrome (ARDS) leading to respiratory failure [4]. Various antiviral drugs are already being used to treat COVID-19 and several clinical trials are underway. Vaccines are also being used to protect people before they are exposed to the SARS-CoV-2 virus. Surfactant therapy has also been used as a supportive symbolic treatment for COVID-19 mortality caused by respiratory failure [5]. Exogenous surfactants are already approved for the treatment of neonatal respiratory distress syndrome and many other lung diseases, and are being used to treat COVID-19 [6]. In addition, several researchers have proposed surfactantbased prevention and therapy to combat the pandemic.

Here, we have highlighted all the exogenous surfactantbased treatments that have been implemented around the world to reduce the risk of lung infection from COVID-19 and help patients recover from respiratory failure. We expect that the scientific community will pay more attention to this promising therapy and basic research on exogenous surfactants will be translated into medical practice.

\section{Pulmonary Surfactant}

In the process of inhalation and exhalation, the lungs are constantly moving. The later one, because of fluid surface ten- 
sion, poses a risk of tissue collapsing. This risk is mitigated by coating lung surfaces with lung surfactant or pulmonary surfactant [7]. The pulmonary surfactant is produced by alveolar type-II cells shortly after birth. The surface tension at airliquid interfaces in the alveoli is reduced by this surfactant, which is composed of $10 \%$ proteins and $90 \%$ lipids [7-9].

Four types of surfactant-related proteins are found in protein components: SP-A, SP-B, SP-C, SP-D. The hydrophilic proteins SP-A and SP-D, commonly known as collectins, are essential for maintaining lung immunity by removing viruses and bacteria. The hydrophobic surface active proteins SP-B and SP-C are important for reducing surface tension at the alveolar air-liquid interface [7, 10].

The lipid part contains $80 \%$ phospholipids and 10\% neutral lipids [8]. Phosphophatidylcholine (PC) is the most important phospholipid component and accounts for more than $70 \%$ of the total lipids. It is the main lipid component of the surfactant and is responsible for reducing the surface tension of the lung. PC is present in both unsaturated (17\%) and saturated forms, especially in dipalmitoylated form (DPPC). Phosphophatidylglycerol has a secondary role in lowering surface tension in the alveoli [10, 11].

SARS-CoV-2 impacts the alveolar type II cells, reducing pulmonary surfactant synthesis and secretion into to the alveoli space, which eventually lead to the lung failure [3, 4, 12]. We can now mimic the role of natural pulmonary surfactant by mixing an exogenous surfactant with certain components, and thereby open an alternative therapeutic path for the treatment of COVID-19 patients [13]. Exogenous surfactant improved oxygenation and restored the lung function, and consequently can be used to prevent COVID-19 pneumonia. In this regard, it is assumed by the researchers that the exogenous surfactant enters lung alveoli after methodical distribution, where the virus encounters these surfactant molecules. The surfactant molecules interact with the spike glycoproteins of the virus in the alveolar space, destroying them.

\section{SARS-CoV-2 structural description and comparison to SARS-CoV}

SARS-CoV-2 is a positive-sense RNA virus with a single strand longer than that found in other RNA viruses [5]. The capsid was formed outside the genome by the nuclcocapsid protein $(\mathrm{N})$, giving it a spherical shape. An envelope encloses the genome, which is then further packaged by three structural proteins. The structural proteins are the membrane protein $(\mathrm{M})$, the spike protein $(\mathrm{S})$ and the envelope protein (E) [14]. Coronavirus enters host cells via the spike glycoprotein (S protein), making it an attractive antiviral target $[4,5]$. The functional components S1 and S2 form the $\mathrm{S}$ proteins. The N-terminal domain (NTD) and receptor binding domain (RBD) of the S1 subunit are responsible for binding to the angiotensin-converting enzyme 2 (ACE2) receptor of the host cell $[4,5,15]$. In contrast, the $\mathrm{S} 2$ subunit has a fusion peptide (FP), a central helix $(\mathrm{CH})$, a transmembrane domain (TM), a cytoplasmic tail (CT) and a heptad repeat (HR1) [16]. The primary function of the unit is to fuse the membranes of viruses and host cells. It also has sixteen non-structural proteins (Nsp 1-16), of which Nsp1 is involved in RNA processing and replication, while Nsp2 controls the host cell survival signalling system.

The unique and deadly SARS-CoV, which produced a pandemic in late 2002 and caused severe acute respiratory syndrome, has a genetic relation with SARS-CoV-2 [17]. Although both had the same receptor (ACE2 receptor) for cell entrance, the SARS-CoV possess the high fatality rate of $11 \%$ [5]. SARS-CoV-2, on the other hand is less lethal but multiplies more easily than SARS-CoV resulting in the current pandemic. SARS-CoV-2 has a 1-2 fold greater affinity towards the ACE2 receptor than SARS-CoV [18]. It was shown that the SARS-CoV carbohydrate moieties contained on the virus's S-protein might bind to the SP-D, limiting the macrophages activation and thus the pulmonary inflammation could be avoided [19]. The natural carbohydrate moiety of S-protein of SARS-CoV-2 is distinct in this case and this research backs up the idea that a lack of collectins serving as host lectins has a significant impact on innate immunity [20]. Table 1 highlighted the comparison of SARS-CoV and SARS-CoV-2.

\section{Type II alveolar cells destroyed by SARS-CoV-2}

According to the crystal structure study, the receptor binding domain (RBD) of SARS-CoV-2 spike protein associated with the cell angiotensin converting enzyme receptor 2 (ACE2), which is found on alveolar epithelial type II cells [3, 4, 20, 21]. Alveolar epithelial cells are squamous cells with cytoplasmic expansion that cover $95 \%$ of the alveolar surface and operate as a vital barrier [14]. By binding to ACE2 receptor, SARS-CoV-2 damaged the type II alveolar cells and as a result, the amount of pulmonary surfactant produced and

\begin{tabular}{|c|c|c|c|}
\hline & SARS-CoV & SARS-CoV-2 & Interpretation \\
\hline transmissibility & 2.4 & 2.5 & average transmissibility of SARS-CoV-2 is higher \\
\hline $\begin{array}{c}\text { percentage of people, experiencing minor } \\
\text { illness }\end{array}$ & Low & High & allows unnoticed transmission \\
\hline incubation period/days & $2-7$ & $1-14$ & $\begin{array}{c}\text { SARS-CoV-2 epidemic form more slowly due to the } \\
\text { longer incubation period. }\end{array}$ \\
\hline risk factors for illness & $\begin{array}{c}\text { increased age, } \\
\text { underlying illness }\end{array}$ & $\begin{array}{c}\text { increased under- } \\
\text { lying illness }\end{array}$ & $\begin{array}{c}\text { concern about capacity in health factor } \\
\text { over } 20 \%\end{array}$ \\
\hline number of patients \\
\hline
\end{tabular}

Table 1 SARS-CoV and SARS-CoV-2 comparison 
secreted into the alveolar space is reduced. The two most serious consequences of surfactant exhaustion are atelectasis of the lungs and ARDS [21]. Moreover, the pulmonary surfactant dysfunction perturbed the air-liquid interphase in SARS-CoV-2 infected patients [12]. The loss of alveolar cells causes a drop in blood oxygen levels, lung fibrosis, delayed regeneration, and oedema, all of which contributes to the collapse of the respiratory system.

A careful investigation revealed that ACE2 is abundantly expressed on the apical surface of the airway epithelia, as well as vascular endothelia, renal and cardiovascular tissues $[15,22]$. Due to the strong expression of the receptors in the upper airways, viral transmission is now quite high. TMPRSS2, a protease associated with viral entry found in the nasal mucosa and bronchial epithelium, is used by SARS-CoV-2 for cellular entry into the upper respiratory tract. ACE2, and not TMPRSS2, appears to be the critical factor for viral entry in the early phase of the disease, as shown by gene expression in different datasets and tissues [22, 23].

Another process that result in the loss of active surfactants is the wound healing process. As a part of coagulation cascade, fibrinogen seeps into the alveolar space, which is then transformed to fibrin. This fibrin now blocks the secretion of lung surfactant, resulting in alveolar collapse [24].

Cytokines are important for embryonic development and also play a crucial role in the defence against infection and other immune responses. Although they play an important role in health care, they have some negative effects that lead to life-threatening diseases [25]. Excessive secretion of cytokines leads to the dangerous cytokine storm syndrome, the prime suspect in the "Spanish flu" pandemic of 1918 [26]. The frequent COVID-19 cases of acute respiratory distress syndrome and multi-organ failure are caused by a cytokine storm. Recent research reported that severely ill patients with COVID19 pneumonia have high levels of pro-inflammatory cytokines such as as IL-6, IL-7, IL-10, IL-2, TNF- $\alpha$ [4, 25]. It has been reported that, SARS-CoV-2 produces a high amount of IL-6 in a selective manner and consequently lymphocytes are exhausted, leading to lymphocytopenia [27]. The severe COVID-19 patients eventually faced respiratory collapse and died.

\section{Surfactant-based therapy against COVID-19}

From the previous explanation, it is clear that reducing the concentration or changing the type of pulmonary surfactant could be a major risk factor for COVID-19. A significant number of COVID-19 patients have respiratory failure requiring the administration of surfactant. Surfactant therapy is already used for respiratory problems. Lung surfactant acts as physiological barrier to viral infection. Immense success has been achieved in treating neonatal RDS with exogenous surfactant therapy and the WHO has already recommended this therapy for neonatal RDS [28]. The lipid moiety of this surfactant showed the antiviral activity and this lipid moiety is solely responsible for the inhibition of H1N1 influenza virus [13]. In addition, the deficit or inactivation of the pulmonary surfactant caused type II alveolar epithelial cell damage, leading to ARDS. Treatment of animal models or humans with ARDS caused by bacterial pneumonia with porcine or bovine pulmonary surfactant was found to have a beneficial effect [5, 29].

Based on this, some authors hypothesized that giving "natural lung surfactant" to COVID-19 pneumonia patients at the early stage of infection could enhance pulmonary function, shortening the time of ventilation therapy and improving patient recovery. Although, COVID-19 viral pneumonia possess comparable symptomatology and pathology with ARDS, neonatal RDS or H1N1 influenza virus, does not respond to a clinical treatment such as exogenous surfactant delivery in the same way. Subsequently, several questions arose in this contest such as what will be the ideal surfactant of using, how administration and timing should be handled, and so on.

Bovine pulmonary surfactant is a lipid extract that comprises $3 \%$ neutral lipid, mostly diacylglycerol and cholesterol. It also has a phospholipid content of $97 \%$. A clinical experiment for COVID-19 patients based on exogenous surfactant therapy termed as LESSCOVID and mainly prepared with bovine lipid extract, has already started at the London Health Science centre in the United Kingdom [30]. Another natural lung surfactant (bovactant) is synthesized by Lyomark Pharma in Germany from lavage bovine lung. It is made up of polar lipids with $41.7 \mathrm{mg} / \mathrm{ml}$ of phospholipid and roughly $1 \%$ of particular low molecular weight SP-B and SP-C proteins [31]. Bovactant surfactant is now being employed as alternative treatment option of COVID-19 because of its potential therapeutics value.

COVsurf, a clinically tested nebulised surfactant, was presented as a potential treatment option for moderate and severe COVID-19 patients [32]. It enters the patient's lungs directly and increases the oxygen levels in the lungs as measured by the $\mathrm{PaO}_{2} / \mathrm{FiO}_{2}$ ratio. Lung ventilation, as determined by the ventilation index, was also improved in this clinical test study [33].

Recent research reports that Curosurf, a non-pyrogenic, sterile pulmonary surfactant, can be used to treat COVID-19 [34]. It consists mainly of the low molecular weight hydrophobic proteins SP-B and SP-C isolated from natural porcine surfactant. It also consists of polar lipids, mainly phospholipids. A dose of $720 \mathrm{mg}$ of Curosurf in $150 \mathrm{ml}$ of normal saline administered via bronchoscopy is safe and practical for COVID-19 patients [35]. Administration of this surfactant reduces mortality and mechanical ventilation duration of the affected patients.

The $\mathrm{KL}_{4}$ surfactant, which efficiently mimics some functional properties of SP-B, generally consists of 1-palmitoyl2-oleoyl-phosphatidylglycerol (POPG), palmitic acid, DPPC and $\mathrm{KL}_{4}$ peptide. It is mainly used for the prevention of neonatal RDS [36]. A detailed comparison of palmitate, colfosceril and artificial non-protein surfactant with $\mathrm{KL}_{4}$ surfactant showed that $\mathrm{KL}_{4}$ surfactant is much more efficient in preventing neonatal RDS. Since $\mathrm{KL}_{4}$ surfactant has the potential to alleviate surfactant deficiency, Windtree therapeutics used the exogenous surfactant for the clinical trial of COVID-19 [12]. Preclinical studies with $\mathrm{KL}_{4}$ surfactant showed that it also has other beneficial properties, such as modulation of the inflammatory process, lack of immunogenicity and antimicrobial properties.

Surfactant CHF5633 is an artificial surfactant consisting of two surfactant proteins: SP-B (0.2\%) and SP-C (1.5\%), reinforcing the role of exogenous surfactant therapy in lung diseases, including COVID-19 [4]. On the other hand, bile salts are steroidal, skeletally rigid surfactants that are biologically processed. Their interfacial behaviour has recently been suggested for the clinical treatment of COVID-19 [29, 37, 38]. The following properties strongly support bile salts for the treatment of COVID-19: 
- Bile salts have an anti-inflammatory property so that they become beneficial in curbing the cytokine storm, one of the fuelling agents of COVID-19 pandemic.

- Due to the amphiphilic nature of the bile salts, they are believed to act as drug carriers and hence they can enhance the intracellular delivery and concentration of drugs like remdesivir and other antiviral chemical agents used for COVID-19 treatment.

- Receptor binding domain of S-glycoprotein of SARSCoV-2 binds with bile salts with negative binding energies. But the impact of their binding on the virus is still under investigation [39].

Exogenous surfactants also possess anti-inflammatory properties and as a result they reduce the secretion of IL-1, IL-6, IL-7 and TNF- $\alpha$ and so on [40]. After ingesting the surfactants, the expression of pro-inflammatory cytokines in the skin wound decreases and as a result of this it contributes effectively to the regeneration of injured alveoli and prevents the failure of respiratory functions. Phospholipids such as palmitoyl-oleyol-phosphatideylglycerol and phosphatidylinositol are used to suppress this pro-inflammatory cytokine secretion [41].

Phosphatidylglycerol (PG) is a significant part of pulmonary surfactant, and it plays a critical function in maintaining lung surface tension $[10,11]$. The activity of secretory phospholipase $\mathrm{A}_{2}$ is increased in ARDS patients, and it is discovered that it destroys phospholipids, particularly PG, by hydrolysis [29]. As a result PG level in the lung decreases and subsequently, exogenous surfactants containing PG are used in ARDS patients to alleviate this condition. Because of the anti-inflammatory effect of PG, it can be utilised to prevent the expression of interleukin components. Surprisingly, these inflammatory components have the ability to raise $\mathrm{SPLA}_{2}$ in the lungs. Based on these lung problems and appropriate therapy, Bollag et al. have recommended the use of a PG-based surfactant to improve lung function in COVID-19 patients [29].

Vitamin D supplementation reduces the chance of influenza and may also help with COVID-19 treatment. SP-A and SP-D in combination with vitamin D reduced the production of cytokines, reduced inflammatory action, and increased phagocytosis, and acted as a first-line protection against lung infections [21, 42].

Sometimes surfactant production are stimulated by the addition of external chemical agents. Bromhexine and ambroxol induce the alveolar type-II cells to produce and secrete pulmonary surfactant [21]. Bromhexine inhibits TMPRSS2 and this inhibition of TMPRSS2, a particular viral entrance is thought to be most effective against SARS-CoV-2. Depending on this, WEPPON pharmaceutical Group Co. Ltd. carried out a clinical trial with bromhexine hydrochloride tablets (BHT). This is the first controlled clinical experiment for the treatment of COVID-19 that has been conducted on a human body [43]. Ambroxol, on the other hand does not inhibit TMPRSS2. In Peking University, researchers of Basic Medicine Sciences experimentally showed that, in accordance with an artificial intelligence (AI) pharmacological target, ambroxol can operate as an ACE2 binder [44]. Furthermore, for the management of COVID-19 sufferers with mild to severe cases, ambroxol has already been used by the researcher of Zhejiang University School of Medicine.

The use of biosurfactants is another potential therapy option for COVID-19 that cannot be overlooked. Although, the researcher has not used this strategy in practice, several publications have suggested the use of biosurfactants for the treatment of COVID-19 patients due to their antiviral and anti-inflammatory properties $[45,46]$. Biosurfactants with the highest antimicrobial activity are of the glycolipid and lipopeptide type. The use of biosurfactants has been suggested by Smith et al. and Subramaniam et al. It is hypothesised that biosurfactant interacts with lipid membrane and disrupts its structure due to its amphiphilic character. After the virus is disrupted, the lipid portions and spike glycoprotein are encased within the biosurfactants-formed micelle, and eventually virulence activity becomes lost. Because of its ability to form micelles, biosurfactants may also be utilised in the delivery of COVID-19 medicines [46].

All of these are currently still in the clinical trial phase and some surfactant-based prophylactics are favoured by the administration of exogenous surfactant. The proposed

\begin{tabular}{|c|c|c|c|c|c|}
\hline \multirow{2}{*}{$\begin{array}{l}\text { Name of } \\
\text { surfactant }\end{array}$} & \multirow[t]{2}{*}{ source } & \multicolumn{2}{|c|}{ composition of the surfactant } & \multirow{2}{*}{$\begin{array}{l}\text { institute adopted } \\
\text { the clinical trials }\end{array}$} & \multirow[t]{2}{*}{ clinical efficacy } \\
\hline & & protein content & lipid content & & \\
\hline $\begin{array}{l}\text { Bovine Pulmonary } \\
\text { Surfactants }\end{array}$ & $\begin{array}{l}\text { recently } \\
\text { butchered } \\
\text { cow lung } \\
\text { lavage }\end{array}$ & $\mathrm{N} / \mathrm{A}$ & $\begin{array}{l}\text { 3\% cholesterol and diacyl- } \\
\text { glycerol, } 79 \% \text { phosphatidyl } \\
\text { choline and } 11 \% \text { phosphati- } \\
\text { dyl glycerol }\end{array}$ & $\begin{array}{c}\text { London Health } \\
\text { Science Centre, UK }\end{array}$ & $\begin{array}{l}\text { limited number of pa- } \\
\text { tients were benefited }\end{array}$ \\
\hline Curosurf & $\begin{array}{l}\text { extracted from } \\
\text { porcine lung }\end{array}$ & $\begin{array}{c}1 \mathrm{mg} / \mathrm{ml} \text { protein } \\
(0.45 \mathrm{mg} / \mathrm{ml} \mathrm{SP}-\mathrm{B} \\
\text { and } 0.59 \mathrm{mg} / \mathrm{ml} \\
\mathrm{SP}-\mathrm{C})\end{array}$ & $\begin{array}{c}76 \text { mg/ml Phospholipids } \\
\text { ( } 55 \mathrm{mg} / \mathrm{ml} \text { Phosphatidylcho- } \\
\text { line, from which } 30 \mathrm{mg} / \mathrm{ml} \\
\text { of DPPC) }\end{array}$ & Versailles Hospital, US & $\begin{array}{l}720 \mathrm{mg} \text { in } 150 \mathrm{ml} \mathrm{sal-} \\
\text { ine solution is effec- } \\
\text { tive and acceptable }\end{array}$ \\
\hline $\mathrm{KL}_{4}$ Surfactant & $\begin{array}{l}\text { synthetic } \\
\text { surfactant }\end{array}$ & $\mathrm{N} / \mathrm{A}$ & $\begin{array}{c}1: 3 \text { mixture of POPG and } \\
\text { DPPC }\end{array}$ & Windtree therapeutics ${ }^{\mathrm{TM}}$ & $\begin{array}{l}\text { reducing inflamma- } \\
\text { tion with improving } \\
\text { lung function, and a } \\
\text { phase } 2 \text { clinical study } \\
\text { is now underway }\end{array}$ \\
\hline $\begin{array}{l}\text { Surfactant } \\
\text { CHF5633 }\end{array}$ & $\begin{array}{l}\text { new genera- } \\
\text { tion synthetic } \\
\text { surfactant }\end{array}$ & $\begin{array}{l}0.2 \% \text { SP B and } \\
1.5 \% \text { SP-C }\end{array}$ & $\begin{array}{c}1: 1 \text { mixture of DPPC and } \\
\text { POPG }\end{array}$ & $\begin{array}{l}\text { Chiesi Farmaceutical, } \\
\text { Italy }\end{array}$ & $\begin{array}{l}\text { improves oxygenation } \\
\text { and reduces the need } \\
\text { for ventilation }\end{array}$ \\
\hline
\end{tabular}

Table 2 Proposed surfactant based therapies 
surfactant-based therapeutics discussed previously are highlighted in Table 2, along with some useful information on the source, composition (protein content and lipid content) and efficacy of the surfactants in mitigating COVID-19 complication. The pulmonary surfactant improved lung function to a greater extent by mitigating alveolar damage and reducing pneumonia. Depending on this, we would like to see surfactant treatment almost completely eliminate surfactant deficiency in COVID-19 affected patients. Therefore, surfactant doses along with the exact timing of administration, the appropriate delivery mechanisms and the selection of a specific, effective drug from a variety of surfactants are other key topics for future research.

\section{Conclusion}

In this paper, we assumed that surfactant-based COVID-19 prevention and therapy would have a better chance of success in the near future, so we explored further new research opportunities. We found that this will require further clinical trials of surfactant-based treatment against COVID-19 and we expect that the success of surfactant therapy will protect the world not only from this current pandemic, but also from any other pandemic in the future. However, to contain the COVID-19 outbreak, people should now avoid crowds and mass gatherings, wear masks and maintain social distance.

\section{Abbreviations}

ACE2 - Angiotensin-converting Enzyme 2

ARDS - Acute respiratory distress syndrome

BHT - Bromhexine hydrochloride tablets

COVID-19 - Coronavirus disease 2019

DPPC - Dipalmitoylphosphatidylcholine (main constituent of pulmonary surfactants)

IL - Interleukin

PC - Phosphophatidylcholine

PG - Phosphatidylglycerol

POPG - 1-palmitoyl-2oleoyl-phosphatidylglycerol

RBD - Receptor binding domain

SARS-CoV-2 - Severe acute respiratory syndrome coronavirus 2

TMPRSS2 - Transmembrane protease, serine 2

TNF - Tumor necrosis factor

\section{Article Note}

All authors have contributed with writing this paper and all authors read and approved the final manuscript.

\section{References}

1. Reported Cases and Deaths by Country or Territory, https://www.worldometers.info/coronavirus/, 2021 (accessed 13 May 2021).

2. One in every three new coronavirus cases globally is reported in India, https:// cnbc.com/2021/05/03india-covid-crisis-charts-show-the severity-of-the-second-wave.html, 2021 (accessed 13 May 2021).

3. Ahmed, S., Akter, M. S., Roy, K., and Islam, M. S.: Role of Surfactant for the Treatment of Alveolar Cells against Coronavirus (Covid-19), Annu. Res. \& Rev. Biol., 35(6) (2020) 34-39. DOI:10.9734/arrb/2020/v35i630233

4. Ghati, A., Dam, P., Tasdemir, D., Kati, A., Sellami, H., Sezgin, G. C., Ildiz, N., Franco, O. L., Mandal, A. K. and Ocsoy, I.: Exogenous pulmonary surfactant: A review focused on adjunctive therapy for severe acute respiratory syndrome coronavirus 2 including SP-A and SP-D as added clinical marker, CURR. Opin. Colloid Interface Sci., 51 (2021) 101413. DOl:10.1016/j.cocis.2020.101413

5. Walther, F. J. and Waring, A. J.: Synthetics Lung Surfactant Treatment for COVID-19 Pneumonia, Coronaviruses, 2 (2021) 8- 10

DOI: 10.2174/2666796701999201014160428

6. Zhang, L., Cao, H., Zhao, S., Yuan, L., Han, D., Jiang, H., Wu, S. and Wu, H.: Effect of exogenous pulmonary surfactants on mortality rate in neonatal respiratory distress syndrome: a network meta-analysis of randomized controlled trials, Pulm. Pharmacol. \& Ther., 34 (2015) 46-54. DOI:10.1016/j.pupt.2015.08.005

7. Chakraborty, M. and Kotecha, S.: Pulmonary surfactant in newborn infants and children, Breathe, 9(6) (2013) 476-488. DOI:10.1183/20734735.006513

8. Griese, $M$.: Pulmonary surfactant in health and human lung disease: state of the art, Eur. Respir. J., 13 (1999) 1455- 1476. PubMed 10445627. DOI: 10.1183/09031936.99.13614779

9. Goerke, J.: Pulmonary surfactant: functions and molecular composition, Biochimica. et. Biophysica. Acta., 1408 (1998) 79-89. DOI:10.1016/S0925-4439(98)00060-X

10. Akella, A. and Deshpande, S. B.: Pulmonary surfactants and their role in pathophysiology of lung disorders, Indian J. of Exp. Bio., 51 (2013) 5-22.

11. Veldhuizen, E. J. A. and Haagsman, H. P.: Role of pulmonary surfactant components in surface film formation and dynamics, Biochimica. et. Biophysica. Acta., 1467 (2000) 255-270. DOI:10.1016/S0005-2736(00)00256-X

12. Mirastschijski, U., Dembinski, R. and Maedler, K.: Lung Surfactant for Pulmonary Barrier Restoration in Patients with COVID-19 Pneumonia, Front. Med., 7 (2020). DOI:10.3389/fmed.2020.00254

13. Pramod, K. Kotta, S., Jijith, U. S., Aravind, A., Tahir, M. A. and Manju, C. S. Surfactant-based prophylaxis and therapy against COVID-19: A possibility, Med. Hypotheses, 143 (2020) 110081 DOI:10.1016/j.mehy.2020.110081

14. Grifoni, A., Weiskopf, D., Ramirez, S. I., Mateus, J., Dan, J. M. and Moderbacher, C. R.: Targets of T cell responses to SARS-Cov-2 coronavirus in humans with COVID-19 disease and unexpected individuals, Cell, 181 (2020) 1489-1501. DOI:10.1016/j.cell.2020.05.015

15. Leeming, D. J., Genovese, F., Sand, J. M. B., Rasmussen, D. G. K., Christiansen, C., Jenkins, G., Maher, T. M., Vestbo, J. and Karsdal, M. A.: Can biomarkers of extracellular matrix remodelling and wound healing be used to identify high risk patients infected with SARS-Cov-2?: Lessons Learned from pulmonary fibrosis, Respir. Res., 22:38 (2021). DOI:10.1186/s12931-020-01590-y

16. Boopathi, S., Poma, A. B. and Kolandaivel, P.: Novel 2019 coronavirus structure, mechanism of action, antiviral drug promises and rule out against its treatment, J. Biomol. Struct. Dyn., 39 (2021) 3409-3418. DOI: 10.1080/07391102.2020.1758788

17. Berger, A., Drosten, C., Doerr, H. W., St?rmer, M. and Preiser, W.: Severe acute respiratory syndrome (SARS)- paradigm of an emerging viral infection, J. Clin. Virol., 29(1) (2004) 13-22. DOI:10.1016/j.jcv.2003.09.011

18. Sun, $P_{.}, L u, X ., X u, C$., Sun, W. and Pan, B.: Understanding of COVID-19 based on current evidences, J. Med. Virol., 92(6) (2020) 548-551. DOI: $10.1002 / j m v .25722$

19. Leth-Larsen, R, Zhong, F. Chow, V. T., Holmskov, U. and Lu, J: The SARS coronavirus spike glycoprotein is selectively recognised by lung surfactant protein $\mathrm{D}$ and activates macrophages, Immunobiology, 212 (2007) $201-211$. DOI:10.1016/j.imbio.2006.12.001

20. Weiskirchen, R: Severity of Coronavirus Disease 2019 (COVID-19): Does Surfactant Matter? Front. microbiol., 11 (2020) 1905. DOI: $10.3389 /$ fmicb.2020.01905

21. Takano, H.: Pulmonary surfactant itself must be a strong defender against SARS-Cov-2, Med. Hypothesis, (2020). DOI:10.1016/j.mehy.2020.110020

22. Sungnak, W. Huang, N., Bécavin, C., Berg, M., Queen, R., Litvinukova, M., Talavera-López, C., Maatz, H., Reichart, D., Sampaziotis, F., Worlock, K. B., Yoshida, M., Barnes, J. L. and H.C.A. Lung Biological Network: SARS-Cov-2 entry factors are highly expressed in nasal epithelia cells together with innate immunity genes, Nat. Med., 26 (2020) $681-687$. DOI: 10.1038/s41591-020-0868-6

23. Qi, F., Qian, S., Zhang, S. and Zhang, Z.: Single cell RNA sequencing of 13 human tissues identify cell types and receptors of human coronavirus, Biochem, Biophys. Res. Commun., 526 (2020) 135- 140 DOl:10.1101/2020.02.16.951913

24. Günther, A., Ruppert, C., Schmidt, R., Markart, P., Grimminger, F., Walmrath, $D$. and Seeger, W.: Surfactant alteration and replacement in acute respiratory distress syndrome, Respi. Res., 2(6) (2001) 1-14. DOI:10.1186/rr86

25. Tang, Y., Liu, J., Zhang, D., Xu, Z., Ji, J. and Wen, C.: Cytokine storm in COVID19: The current evidence and treatment Strategies, Front. Immunol., (2020) 1708. DOI:10.3389/fimmu.2020.01708

26. Woo, G.: Age-dependence of the 1918 pandemic, Br. Actuar. J., 24 (2018) 1 16. DOI: $10.1017 / \mathrm{S} 1357321719000023$

27. Shi, Y., Wang, Y., Shao, C., Huang, J., Gan, J., Huang, X., Bucci, E., Piacentini, M., Lppolito, G. and Melino, G.: COVID-19 infection: The perspectives on immune responses, Cell Death Differ., 27 (2020) 1451 - 1454. DOI: 10.1038/s41418-020-0530-3

28. World Health Organisation: WHO recommendation on surfactant replacement therapy for newborns with respiratory distress syndrome. https://extranet.who.int/rhl/topics/newborn-health/care-newborn-infant/who-recommendation-surfactant-replacement-therapy-newborns-respiratory-distress-syndrome/, 2015 (accessed 13 May 2021).

29. Bollag, W. B. and Gonzales, J. N.: Phosphatidylglycerol and surfactant: A potential treatment for COVID-19?, Med. Hypothesis. 144 (2020) 110277. DOI:10.1016/j.mehy.2020.110277 
30. US National Library of Medicine, Clinical Trials.gov Identifier: NCT04375735: London's exogenous surfactant study for COVID 19 (LESSCOVID). https:// clinicaltrials.gov/ct2/show/NCT04375735, 2020 (accessed 13 May 2021).

31. Davidson, W. J., Dorscheid, D., Spragg, R., Schulzer, M., Mak, E. and Ayas, N. T.: Exogenous pulmonary surfactant for the treatment of adult patients with acute respiratory with acute respiratory distress syndrome: results of a meta-analysis, Crit. Care. 10 (2006). DOI:10.1186/cc4851

32. US National Library of Medicine, Clinical Trials.gov Identifier: NCT04362059: A clinical trial of nebulized surfactant for the treatment of moderate to severe COVID-19 (COVSurf). https://clinicaltrials.gov/ct2/show/NCT04362059, 2020 (accessed by 13 May 2021).

33. Dushianthan, A., Clark, H., Madsen, J., Mogg, R., Matthews, L. et al.: Nebulised surfactant for the treatment of severe COVID-19 in adults (COV-Surf): A structured summary of a study protocol for a randomized controlled trial, Trials, 21 (2020) 1014. DOI:10.1186/s13063-020-04944-5

34. US National Library of Medicine Clinical Trials oov Identifier: NCT04384731: Randomized Controlled Phase II Trial of Poractant Alfa (Curosurf) by Fiberoptic Bronchoscopy-directed Endobronchial Administration in Acute Respiratory Distress Syndrome (ARDS) Due to COVID-19 Viral Pneumonia. https://clinicaltrials.gov/ct2/show/NCT04384731, 2020 (accessed 13 May 2021).

35. Piva, S, Robert, D, Slee, A. E, Jobe, A. H, Roccaro, A. M, Filippini, M, Latronico, N., Bertoni, M., Marshall, J. C. and Portman, M. A.: Surfactant therapy for COVID-19 related ARDS: A Retrospective case-control pilot study, Respir. Res., 22 (2021) article no 20. DOI:10.1186/s 12931-020-01603-w

36. Sáeng, A. Álvarez, L. Santos, M., López-Sánchez, A., Castillo-Olivares, J. L Varela, A., Segal, R. and Casals, C.: Beneficial effects of synthetic KL4 surfactant in experimental lung transplantation, Eur. Respir. J., 37 (2011) 925-932. DOI:10.1183/09031936.00020810

37. Hofmann, A. F. and Mysels, K. J.: Bile salts as biological surfactants, Colloids Surf. 30 (1987) 145-173. DOI:10.1016/0166-6622(87)80207-X

38. Di Gregorio, M. C., Travaglini, L., Giudice, A. D. and Cautela, J.: Bile Salts: Natural surfactants and precursors of a board family of complex amphiphiles, Langmuir, 35(21) (2019) 6803-6821. DOI:10.1021/acs.langmuir.8b02657

39. Kumar $Y$ Yadav $R$ and Bhatia, A.: Can natural detergent properties of bile acids be used beneficially in tacking coronavirus disease-19?, Future Virol., (2020). DOI: 10.2217/fvl-2020-0210

40. Han, S. and Mallampalli, R. K.: The role of surfactant in lung disease and host defence against pulmonary infections, Ann. Am. Thoarc. Soc., 12 (2015) $765-$ 774. DOI 10.1513/AnnalsATS. 201411-507FR.

DOI:10.1513/AnnalsATS. 201411-507FR

41. Numata, M., Chu, H. W., Dakhama, A. and Voelker, D. R.: Pulmonary surfactant phosphatidylglycerol inhibits respiratory syncytial virus-induced inflammation and infection, Pro. Natl. Acad. Sci., 107 (2010) 320-325. DOI:10.1073/pnas.0909361107

42. Poorna, P. and Biswal, N.: Respiratory infections: Role of vitamin D and surfactant proteins A and D, Lung India. 37(5) (2020) $421-424$. DOI:10.4103/lungindia.lungindia 36918

43. Depfenhart, M., de Villiers, D., Lemperle, G., Meyer, M. and Di Somma, S.: Potential new treatment stratiges for COVID-19: is there a role for bromhexine as add-on therapy?, Intern. Emerg. Med., 15 (2020) 801 - 802 DOI: 10.1007/s11739-020-02383-3

44. Olaleye, O. A, Kaur, M. and Onyenaka, C. C.: Ambroxol hydrochloride inhibits the interaction between severe acute respiratory syndrome coronavirus 2 spike protein's receptor binding domain and recombinant human ACE2. (2020). DOI: 10.1101/2020.09.13.295691

45. Subramaniam, M. D., Venkatesan, D., Iyer, M., Subbarayan, S., Govindasami V., Roy, A., Narayanasamy, A., Kamalakannan, S., Gopalakrishnan, A. V., Thangarasu, R., Kumar N. S. and Vellingiri, B.: Biosurfactants and anti-inflammatory activity: A potential new approach towardsCOVID-19, Curr. Opin. Environ. Sci. Health, 17 (2020) 72 - 81. DOI:10.1016/j.coesh.2020.09.002

46. Smith, M. L., Gandolfi, S., Coshall, P. M. and Rahman, P. K. S. M.: Biosurfactants: A COVID-19 perspective, Front. Microbiol., 11 (2020) article no 1341. DOI:10.3389/fmicb.2020.01341
Received: 19.06.2021

Accepted: 29.07.2021

\section{Bibliography}

DOI 10.1515/tsd-2021-2382

Tenside Surf. Det. 58 (2021) 6, page 410-415

(c) 2021 Walter de Gruyter GmbH, Berlin/Boston, Germany

ISSN 0932-3414 · e-ISSN 2195-8564

\section{Correspondence address}

\section{Bidyut Saha}

Homogeneous Catalysis Laboratory

Department of Chemistry

The University of Burdwan

Burdwan, 713104

West Benga

India

E-mail: b_saha31@rediffmail.com

\section{The authors of this paper}

Dr. Bidyut Saha: He was born in Birbhum, WB, India, in 1975. He obtained his Ph. D. degree from Visva Bharati University, India in 2007. He was a visiting scientist for the year 2009- 2010 in the Department of Chemistry, UBC, Canada. Dr. Saha is presently working as a Professor in the Department of Chemistry, Burdwan University, India. His area of interests is bioremediation of toxic metals, micellar catalysis and inorganic reaction mechanism. He has already published 141 papers in international journals.

Dr. Bula Singh received her B.Sc. and M. Sc. from the Department of Chemistry, Visva-Bharati University with specialisation in physical chemistry in 1996 and 1998 respectively. She received her Ph. D. from Jadavpur University. She is currently working in the Department of Physical Chemistry at the Department of Chemistry, VisvaBharati University.

Sk Mehebub Rahaman was born in West Bengal, India, in 1996. He received his B. Sc. (Hons. in Chemistry) from the Burdwan Raj College in 2017. He completed his M. Sc. Degree at The University of Burdwan in 2019 and now he is pursuing his Ph.D. at the University of Burdwan under the supervision of Prof. B. Saha.

Budhadeb Chowdhury was born in West Bengal, India, in 1989. He received his B. Sc. (Hons. in Chemistry) at the Bankura Christian College in 2009. He completed his M. Sc. Degree at the University of Burdwan in 2011 and is now pursuing his Ph. D. at the University of Burdwan under the supervision of Prof. B. Saha.

Animesh Acharjee was born in Raniganj, WB, India, in 1989. He received his M.Sc degree from Burdwan University in 2013. He is currently working as an Assistant Professor at Hooghly Mohsin College and is also a research scientist in the Homogeneous Catalysis Laboratory at Burdwan University. 